\title{
Lord Porritt
}

The obituaries on pages 77 and 78 chronicle the facts of the life of one of the most remarkable men of our time, Arthur Porritt. None could fail to be amazed, if not bemused, by the distinction of his professional achievements, the wide scale of which would probably now be impossible to attain in a much changed world. Certainly, his was a career accelerated and projected well beyond surgery by the intervention of the Second World War which, sadly, gave the fullest scope for so many to face and have to surmount new challenges outside most peacetime experience.

' $\mathrm{AP}^{\prime}$ was a born leader; charismatic before that word became devalued. He had that natural bearing which commanded respect rather than awe and most were content to defer to that innate authority without feeling belittled. His empathy made him a sympathetic listener and adviser in times of difficulty. He would support his student clubs with unfailing loyalty and generosity - and greet his students by name. His precision and punctuality were bywords and surely the key to an amazingly full diary of commitments. He would, being the busiest of men, always have that moment to advise and guide without appearing hurried or condescending.

He was always proud of his cofoundation, with that other distinguished medical knight Sir Adolphe Abrahams, of the British Association of Sport and Medicine. He continued to support both BASM and the wider cause of sports medicine to the end of his life and was an early supporter of the idea of a Sports Medicine section of the Royal Society of Medicine, which came to fruition just 3 months after his death. His efforts in the mid-1970s with Lord Luke to secure a rapprochement between BASM and the Institute of Sports Medicine were determined, but doomed to be one of his few failures.

Arthur Porritt had broad vision. He had the gift not only of delegation, but of positively encouraging his young protégés to 'run with the ball'. He was above professional jealousy and pettiness and few errant students needed a second lesson in that!

As we remember our Founder, we could do worse than to stop for a moment and wonder what he would have thought of some of the political messes his successors have managed to contrive. Can we honour him most effectively by learning from his efforts to put the grand vision above internecine strife?

Peter Sperryn Editor-in-Chief 